\title{
Between the Fears and Hopes for a Different Future for the Nation-states: Scholarship Programs in Saudi Arabia and United Arab Emirates from a Public Policy Standpoint
}

\author{
Kholoud T Hilal ${ }^{1}$ \\ ${ }^{1}$ University of New England, Armidale, Australia \\ Correspondence: Kholoud T. Hilal, UNE school of Business, University of New England, Armidale, NSW 2351, \\ Australia. Tel: 61-2-6773-5062. E-mail:khilal@une.edu.au \\ Received: April 3, 2013 \\ Accepted: May 13, 2013 \\ Online Published: May 14, 2013 \\ doi:10.5430/ijhe.v2n2p195 \\ URL: http://dx.doi.org/10.5430/ijhe.v2n2p195

\begin{abstract}
As Bereday (1964) once said, comparative education research, in its most rudimentary form, begins with juxtaposition. When juxtaposing contemporary trends concerning higher education in Saudi Arabia and the United Arab Emirates---both of which currently provide substantial support to improve their higher education systems---differences abound in terms of approach, strategic 'cultural' foresight, openness, and outreach. What do Saudi Arabia and United Arab Emirates aim to achieve via overseas scholarship programs? How do overseas Saudi and Emirati students evaluate the scholarship programs in terms of its negative and positive impacts on Saudi Arabia and United Arab Emirates? Among other things, this research highlights some of the similarities and differences between Saudi and Emirati students regarding their evaluation of Saudi Arabia's and United Arab Emirates' scholarship programs. This research has been conducted by a Saudi-PhD-sponsored by King Abdullah Scholarship Program; therefore, more emphasis will be placed on Saudi Arabia. While, in some parts, the study compares Saudi and Emiratis students, Emiratis and/or United Arab Emirates has been chosen in order to set KSA higher education in the context of another major Arab state.
\end{abstract}

Keywords: Saudi Arabia, UAE, Higher Education, Scholarship Programs, and Identity, Nationalism, Transnationalism, Cosmopolitanism

\section{Introduction: Understanding Context in the Arab-Speaking World}

Higher education has a longstanding history in the Arab-speaking world with a number of institutions that have existed well before their counterparts in Western Europe. Among those that have been recognized worldwide include the University of Al-Karaouine (Morocco); Al-Azhar (Egypt); Jundishapur University (Iran); Munstansiriya University (Iraq) and Nazamiyya (Iran). These institutions, including the famous library, 'the House of Wisdom' (Baghdad)---founded in 765 BCE (Lyons 2010)---were considered magnets for knowledge-seeking European travelers during the Renaissance era. This appears to confirm a form of educational borrowing known as 'travelers' tales', a phrase coined by Noah and Eckstein, which describes how educational observers would travel to distant lands to learn about 'best practice' and bring their tales home for dissemination (Noah and Eckstein 1998; Denman 2004). Moreover, "Medieval Western scholars who wanted access to the latest findings also needed to master the Arabic tongue, or work from translations by those who had done so. It is also worth noting that such labels, today largely associated with nation-states and the demands for distinct cultural identity, were far more fluid in the era under discussion" (Lyons, 2010, p. ix).

In the Arab world, the university in itself was not perceived to be important to the student; the student's relationship with his teacher was more significant. "A group of disciples centering round the same master was often described poetically as a chorus or a 'thiasos' or a fraternity...so that the spiritual bond that untied them had an almost sacred character" (Marrou, 1956, p. 197).

It is therefore important to understand the geo-political context of this important region holistically from a comparative education standpoint, as what is typically understood about comparative education in a Western -based context is not applicable in the Middle-Eastern milieu. 
Table 1. Comparing Geo-Political Contexts

\begin{tabular}{|c|c|}
\hline Kingdom of Saudi Arabia (KSA) & United Arab Emirates (UAE) \\
\hline $\begin{array}{l}\text { KSA occupies an area of over } 2 \text { million square } \\
\text { kilometers, of which is composed of } 13 \text { administrative } \\
\text { provinces with a total population estimated at } 27.56 \\
\text { million. ( } 31 \% \text { are non-Saudis). }\end{array}$ & $\begin{array}{l}\text { UAE is approximately } 77,700 \mathrm{~km} \text { with a current } \\
\text { population of } 4,598,600 \text { (World Bank Development } \\
\text { Indicators: online). Population of non-Emiratis is } \\
\text { estimated at } 23 \% \text {. }\end{array}$ \\
\hline $\begin{array}{l}\text { The annual growth in KSA has been estimated at } 3.2 \% \text {, } \\
\text { based on the two census reports of } 2004 \text { and } 2010 \text { with } \\
45.76 \% \text { of the population under } 20 \text { years of age. }\end{array}$ & $\begin{array}{l}\text { UAE's growth has declined from } 7.4 \% \text { in } 2008 \text { to } \\
3.3 \% \text { in } 2009 \text { (IMF: online), suggesting that the } \\
\text { Global Financial Crisis has had some impact on the } \\
\text { nation. } 51.1 \% \text { of nationals are under } 20 \text { years of age. }\end{array}$ \\
\hline $\begin{array}{l}107,706 \text { students are currently studying abroad under } \\
\text { the King Abdullah Scholarship Program (KASP), a } \\
\text { government initiative intended to diversify employment } \\
\text { in the Kingdom and to offer new opportunities for } \\
\text { selected students. Approximately } 16,000 \text { are } \\
\text { self-funded. }\end{array}$ & $\begin{array}{l}\text { Ahmed in Gonzalez (2008: 103) estimates that } \\
\text { approximately 2,500 Emirati students studied abroad } \\
\text { in higher education institutions in 2003. This modest } \\
\text { figure may be due to the number of foreign higher } \\
\text { education providers located in UAE. }\end{array}$ \\
\hline $\begin{array}{l}\text { Gender segregation policy for students and staff in all } \\
\text { the universities (except for KAUST). }\end{array}$ & $\begin{array}{l}\text { Less than } 30 \% \text { of the universities have a policy on } \\
\text { gender segregation. }\end{array}$ \\
\hline $\begin{array}{l}\text { Arabic is taught in all government universities with the } \\
\text { exception of some disciplines such as medical science, } \\
\text { aviation and English, which are taught in English. }\end{array}$ & $\begin{array}{l}\text { Arabic is taught in government universities with the } \\
\text { exception of Al-Sheikh Zayed University, which uses } \\
\text { English for instruction. }\end{array}$ \\
\hline English is taught in private universities and colleges. & $\begin{array}{l}\text { Teaching in other foreign languages depends on the } \\
\text { origin of the provider (foreign providers). }\end{array}$ \\
\hline
\end{tabular}

From a Western perspective, KSA and UAE reflect very little difference in their practices other than the points noted in Table 1. Both countries use Arabic as their national language, although there are changes underway in migration patterns. UAE has experienced exponential growth in Indian, Pakistani, and Bangladeshi populations, and while these groups may be offered UAE citizenship, Saudi Arabia does not permit this. Regardless, the rise in foreign populations of both countries has created clustered groups living principally in urban areas who speak languages other than Arabic. As a result, Urdu and Hindi are now considered official languages of UAE.

According to official government websites and statistics, citizens of both KSA and UAE are 100\% Muslims; however, this information is not very accurate. Legally, non-Muslims are not allowed to hold Saudi citizenship, but in the UAE, some immigrants are granted this privilege. Obviously, Islam plays a major role in molding and shaping these two countries in terms of their respective cultural identities, but the principal differences in each rest in generational traditions and customs which have been passed down through families and family ties. Islam tends to define dimensions of all types of relationships in each society, explains why sons and daughters should and must honor their parents, and Islam spells out the accepted and non-acceptable kinds of food, drink, and relationship boundaries. KSA tends to be more conservative and traditional compared to the UAE, which is more flexible in approach.

\section{Why is Saudi Arabia different from other countries?}

There are a number of unique characteristics that differentiate Saudi Arabia from all other countries in the world. For example, it may be easier to cluster them as things you see in Saudi Arabia and may not be seen elsewhere; and things that do not exist in Saudi Arabia and are easily found almost everywhere else. On the one hand, what can you not find in Saudi Arabia? Saudi Arabia is the only country that does not permit multi faiths for its citizens. Selling alcohol is not tolerated except in the foreign embassies. Women are not allowed to drive cars until this moment. Moreover, cinemas are not to be found in Saudi Arabia (except in some foreign compounds i.e. ARAMCO). Finally, when it is prayer time in the mosques, all shops have to close until prayer is over.

On the other hand, what can you see in Saudi Arabia but not in many other places? Segregation policy between men and women is applied in most of the schools, universities, restaurants, in all mosques---except the holy mosque in Makkah, the separation between genders also covers the waiting areas in hospitals and clinics. KSA is the only country that has Thursday and Friday as weekend days. Nevertheless, this does not determine how good or bad this society is, but to indicate that it is a conservative and unique society with its religious and cultural aspects. 


\section{Saudi Arabia and United Arab Emirates Political, Economic and Social challenges}

Saudi Arabia and United Arab Emirates have a number of internal issue (economic and social), as well as external issues (politics). The table below summarizes the most concerning ones.

Table 2. Political, Economic and Social Challenges to KSA and UAE

\begin{tabular}{l} 
Political Level \\
\hline KSA and UAE are challenged to \\
reconsider and amend the \\
immigrant labor rights in order \\
to avoid clashes with their \\
source countries. After all, KSA \\
and UAE are less likely to \\
pursue a common policy to \\
manage immigration.
\end{tabular}

Because of the increasing population growth which will mainly remain concentrated in cities, a number of considerable pressure is being put on governments as the public services and infrastructure in those cities have to modify to absorb the needs and numbers of this populations.

As the numbers of graduate students are noticeably increasing, it becomes so challenging for the governments to provide every graduate a job (Gause 2002: 42).

After the war of Iraq, sect wars have erupted between Sunni and Shi'a. Because KSA and UAE have these two sects, the governments are concerned about policies that can maintain peace.

In light of the Arab Spring, the GCC governments will have to react through a mix of economic and political reforms in order to avoid a revolution. They also have to set up a plan or policy to deal with any potential protests.

\section{Economic Level}

KSA and UAE are anticipated to continue pursuing a strong market demand due to the robust population growth, the affluence of the regions, together with its ample natural resources. As a result, the region will continue to be an attractive destination for foreign investors. "At the same time, the region's long-term economic growth will depend critically on the success of efforts to educate and employ the rapidly expanding young population"

The rapid growth will also affect the labors. For instance, the mismatches (between curricula and market demands) will not only be in the area of skills, but also that of expectations of salaries and working conditions. From an optimistic perspective, ongoing education reforms will help, however, it is not anticipated to solve these mismatches within the next ten years.

The doors for women to enter the labor force are more welcoming than ever and it is more likely that the number of working women is going to increase over the next years. Subsequently, businesses will face pressure to offer and provide more and more jobs to absorb these female workers.

Nationals are pressuring the KSA's and UAE's governments to prioritize them over foreign workers. In other words, there are parallel pressures from groups that want to protect jobs for nationals and those that want more rights for immigrations.

The private sector is heavily dependent on expatriates while the government bureaucracy and the public sector employ the bulk of the nationals. Among other reasons, the lack of well-planned educational policy has contributed to these

\section{Social Level}

KSA and UAE are within the region that is considered as one of the fastest-growing populations worldwide (Gulf Arab Region). The estimation is that by 2020 this population will increase by one-third, to around $53 \mathrm{~m}$ people. The majority of this population will be under 25 years of age. Although this rapid growth and the relative youth of the population present major opportunities, they represent serious challenges as well.

As part of the modernization and urbanization, young people in KSA and UAE are going more towards the up-word mobility. In other words, "showing off" is a big phenomenon there. As a result, the Gulf Arab States are now known as one of the best places for shopping worldwide.

The identity, social attitudes and norms of the young Saudis and Emiratis may possibly change and be influenced by the potential increasing access to education as well as the international media and the new technologies which may threaten their identity and attachment to Islam's rules.

The increasing number of working women represents a chance that this will result in a change in social attitudes and the creation of role models for a new generation of working women. This may threaten the identity of the culture.

As the KSA and UAE have recently started extensive overseas scholarships programs, the students will be back with different ideas, thoughts and manners that may conflict and affect the Islamic and cultural ones. 
"Public Opinion" is becoming increasingly significant in KSA and UAE. In the past, Gulf Arabs, in general, were more "obedient" to their monarchs yet they are now more aware of their rights. Hence KSA's and UAE's governments are asked to meet their expectations and provide them with their necessary and luxury needs (Gause 1994: 147-148). Including better universities, hospitals, jobs, entertainments, etc.

KSA's and UAE's governments have to provide certain types of jobs as young Gulf Arabs would not accept any kind of jobs. Gause says: "access to great wealth has allowed Gulf countries the luxury of paying other people to do their 'dirty work" (1994; 151). KSA's and UAE's governments have to find a way in order to shift attitudes and perception. imbalances in the labor force.

Nonetheless, education reforms alone will not be sufficient to make a major change to the structure of the KSA's and UAE's labor force, as skills shortages are not the only reason that private-sector employers generally prefer to recruit expatriates. Issues of cost, productivity, work ethic and the balance between worker and employer rights all contribute to this preference for expatriates.

Foreign workers have been an important part of the labor force in KSA and UAE, for several decades. Their contribution to the socio-economic development in the region has been substantial. This heavy dependence on expatriates can be explained by the availability of financial resources and the lack of human ones. In other words, the ambitious schemes to create a modern infrastructure, funded by oil revenues, lack the necessary human-power to carry them out. Consequently, foreign workers from all over the world were employed by the Gulf states creating a heavy native dependence on expatriates not only in quantitative but also in qualitative terms.
Again, due to the globalization and modernization, the parents are losing some of their power over their children. For example, years ago, parents in KSA and UAE were strict and would not allow their daughters to study or work. Parents would also not accept any marriage based on a love story; however, this has been changing in the recent years. The younger generation is becoming more independent which can be both good and bad.

The sense of obligation to the extended families has been under threat due to the changes in the work life and social system (Davis et el 2007).

Sources: Bahgat 1999; Barber et el 2007; Davis et el 2007; Economist a 2009; http:/graphics.eiu.com/marketing/pdf/Gulf2020.pdf $\quad$ Economist $\quad b \quad$ 2009; http://graphics.eiu.com/upload/eb/Gulf2020part2.pdf Gause 1994; Gause 1997; Gause 2002; Gulf Talent.com; and http://www.gulftalent.com/home/Employment-and-Salary-Trends-in-the-Gulf-2012-Report-33.html Kapiszewski 2006.

\section{Higher Education in KSA and UAE}

In examining the subject of higher education marketing and promotion, it is important to consider both financial and ideological dimensions. Generally speaking, in relation to finance, an ongoing challenge faced by most governments is how to best meet the costs of a mass system of higher education. A common policy response has been to pressure higher education institutions themselves into seeking a greater proportion of their revenue from other sources through diversification of funds. Another marketing policy dimension involves the dynamic between higher education and the state as well as higher education and society. There is some evidence that marketing higher education is fundamentally changing governance and management relationships insofar as skills migration and knowledge management are concerned. Both rely on the expertise of highly skilled academic staff, specific curricula 
that have direct application to industry-ready professions (e.g. petroleum engineering), and academically motivated students who have key core competencies in their disciplinary interests.

Generalizations aside, however, there are several distinct points to be made about marketing and promoting higher education in Saudi Arabia and United Arab Emirates that point to differences in university expansion. First is the recent proliferation of institutions established in Saudi Arabia. Currently, there are 24 government universities (free of charge), eight private universities, and 20 private colleges.

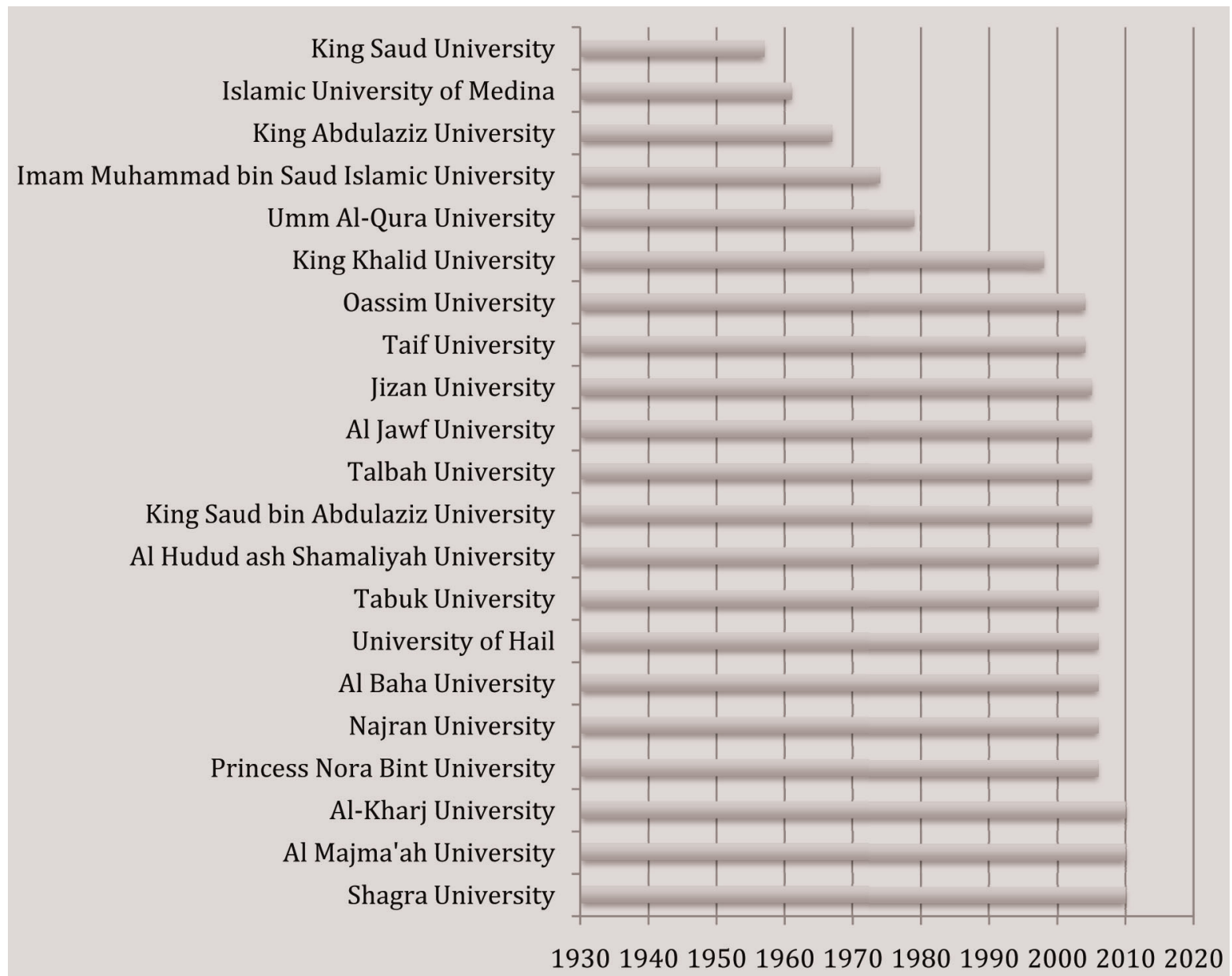

Figure 1. Founding Dates of Government Universities in Saudi Arabia

Source: Saudi Ministry of Higher Education 2011

The number of KSA government or public universities has increased from three to 24 in the period 1970-2011. This growth can be partially attributed to the formation of branch campuses from well-established Saudi universities that recently became independent. Of the eight private institutions, all have been founded since 2002. This suggests a pivotal change in higher education provision. Emphasis in KSA appears to be placed on developing higher education internally, whereas in the UAE, the country appears to be promoting higher education externally by granting foreign higher education providers access.

Currently, the UAE has 49 foreign higher education providers. See table 3. 
Table 3. Foreign higher education institutions in the UAE

\begin{tabular}{|c|c|c|c|}
\hline 1 & Middlesex University Dubai (UK) & 13 & Szabist (Pakistan) \\
\hline 2 & Heriot-Watt University (UK) & 14 & Islamic Azad University (Iran) \\
\hline 3 & University of Bolton (UK) & 15 & Michigan State University (USA) \\
\hline 4 & $\begin{array}{l}\text { American University in the Emirates } \\
\text { (USA) }\end{array}$ & 16 & Paris-Sorbonne University Abu Dhabi (France) \\
\hline 5 & $\begin{array}{l}\text { Birla Institute of Technology and } \\
\text { Science Pilani (India) }\end{array}$ & 17 & American University of Sharjah (USA) \\
\hline 6 & $\begin{array}{l}\text { Birla Institute of Technology Ranchi } \\
\text { (India) }\end{array}$ & 18 & HULT International Business School (USA) \\
\hline 7 & University of Wollongong (Australia) & 19 & New York Institute of Technology (USA) \\
\hline 8 & $\begin{array}{l}\text { School of Audio } \\
\text { (Australia) }\end{array}$ & 20 & Preston University Ajman (USA) \\
\hline 9 & Murdoch University (Australia) & 21 & Cambridge College International (Australia) \\
\hline 10 & $\begin{array}{l}\text { European University College, Brussels } \\
\text { (Belgium) }\end{array}$ & 22 & JSS Academy, Dubai (India) \\
\hline 11 & $\begin{array}{l}\text { Manipal Academy of Higher Education } \\
\text { (India) }\end{array}$ & 23 & Mahatma Gandhi University (India) \\
\hline 12 & $\begin{array}{l}\text { Frankfinn Institute of Air Hostess } \\
\text { Training (India) }\end{array}$ & 24 & Canadian University of Dubai (Canada) \\
\hline 25 & American University in Dubai (USA) & 37 & British University in Dubai (UK) \\
\hline 26 & $\begin{array}{l}\text { Sharjah College - Troy University } \\
\text { Campus (USA) }\end{array}$ & 38 & ICFAI, Dubai (India) \\
\hline 27 & St Petersburg State University (Russia) & 39 & Institute of Media and Communication (India) \\
\hline 28 & $\begin{array}{l}\text { IITM - London School of Economics } \\
\text { (UK) }\end{array}$ & 40 & Institute of Management and Technology (India) \\
\hline 29 & French Fashion ESMOD (France) & 41 & Rochester Institute of Technology Dubai (India) \\
\hline 30 & London Business School (UK) & 42 & $\begin{array}{l}\text { Boston University Institute for Dental Research } \\
\text { (USA) }\end{array}$ \\
\hline 31 & $\begin{array}{l}\text { Manchester Business School } \\
\text { Worldwide (UK) }\end{array}$ & 43 & SP Jain Center of Management, Dubai (India) \\
\hline 32 & $\begin{array}{l}\text { University of Strathclyde Business } \\
\text { School (UK) }\end{array}$ & 44 & PIM International Center, Dubai (Sri Lanka) \\
\hline 33 & CASS Business School (UK) & 45 & $\begin{array}{l}\text { Masdar Institute of Science and Technology } \\
\text { (USA) }\end{array}$ \\
\hline 34 & $\begin{array}{l}\text { School of Oriental and African Studies } \\
\text { (UK) }\end{array}$ & 46 & Harvard Medical School Dubai Centre (USA) \\
\hline 35 & University of Exeter (UK) & 47 & INSEAD (France) \\
\hline 36 & Royal College of Surgeons (UK) & 48 & $\begin{array}{l}\text { Johns Hopkins Bloomberg School of Public } \\
\text { Health (US) }\end{array}$ \\
\hline
\end{tabular}

Source: British Council, TNE in the UAE Research Findings, 2009.

Among the 49 higher education institutions located in the UAE, 32\% are international---only $13 \%$ are accredited by the Ministry of Higher Education and Scientific Research---and 48\% of the total student population in these foreign providers have matriculated from five institutions only. These are the American University of Sharjah, the American 
University of Wollongong, Manipal Academy of Higher Education, and Birla Institute of Technology (British Council 2009).

\subsection{Ministries of Higher Education (MoHEs) in KSA and UAE}

Another shared characteristic between KSA and UAE is 'student mobility'---the movement of students from their origin countries who seek university degrees in host countries. The mobility movement in both countries has specific implications for scholarship programs. Both governments offer a unique open-handed external and internal scholarship program. In both countries, each program sponsors highly qualified Saudi and Emirati students to undertake higher education studies abroad (bachelors, masters, doctorate, and/or medical fellowship). Nominated students/candidates must meet academic standards set by the Ministry of Higher Education. Each program operates under the supervision of their respective Ministries of Higher Education.

Saudi Arabian 'MoHE' offers 58 recommended countries available to Saudi students under the auspices of the King Abdullah Scholarship program (KASP Scholarship). Emirati's 'MoHE' offers 46 recommended countries for UAE students. The number of sponsored students is not available.

\section{Expected Role of Higher Education and overseas scholarship program}

While Saudi Arabia and United Arab Emirates have a very similar culture, norm, political, economic and social challenges, the data is insufficient to assume what UAE wants to achieve by sending its students overseas. In the case of Saudi Arabia, however, there are three assumptions for establishing the King Abdullah Scholarship Program (KASP):

\subsection{Assumption 1: KASP was founded on a political ground}

There is a strong link between the foundation of KASP and September $11^{\text {th }}$ terrorist attack in 2001. The ramifications of 9/11, especially on Saudi Arabia, have continued until recently. For instance, since 15 of the 19 hijackers were Saudis, more restrictions were placed on issuing visas for Saudis "the open door for Saudi students slammed shut in 2001" (Knickmeyer, 2012, para. 39), and there were approximately 1,000 Saudi students studying in the States in 2004 (Knickmeyer, 2012, para. 5). Generally, the discrimination against Arabs/Muslims particularly Saudis took different forms. For example, Sami Al-Obeid's U.S. visa was revoked without explanation, and he could not finish his U.S. degree (Knickmeyer, 2012, para. 40). In other words, U.S. universities lost around $\$ 40$ million a year in tuition from Middle Eastern students after 9/11 (Knickmeyer, 2012, para. 41).

Four years later, King Abdullah bin Abdul-Aziz was proclaimed as the sixth King of the Kingdom of Saudi Arabia, on $1^{\text {st }}$ August 2005. Accordingly, in 2005 and 2006, he visited many influential countries for the purpose of strengthening the international's relations between Saudi Arabia and the rest of the world (Zeigler, 2012, para. 12).

In 2005, most importantly, King Abdullah visited the United States and met President George W. Bush (Royal Embassy of Saudi Arabia in Washington, DC, 2011, para. 14). King Abdullah persuaded President George W. Bush to reopen the student visa service for Saudi students after September $11^{\text {th }}$ by assuming that the "education" program is crucial for the Saudi-U.S. long-term relationship (Knickmeyer, 2012, p. 16). Ultimately, that meeting between King Abdullah and President Push has resulted in KASP, which is the largest overseas scholarship program worldwide. The Pie News states that KASP was established mainly to help Saudi Arabia rebuild the international relations with the West after the $9 / 11$ terrorists' attack (Thomas, 2013, para. 1).

So, clearly, there is a connection between KASP and the willingness to amend 9/11 ramifications, maintain international relations, to correct its stereotype, and re-locate itself in the world map (Denman \& Hilal 2011). In another study, KASP was described to be a tool for peace (Hilal \& Denman 2013), and it was described as a strategy to turn the barriers between cultures into bridges (Denman \& Hilal 2011). Knickmeyer states: "The impassioned plea that the King made for this, and the long-term importance of the relationship, really made an impression on President Bush" (2012, para. 17).

\subsection{Assumption 2: KASP was founded on an economic ground}

The majority of the literature tends to assume that the main reason for founding KASP is for economic purposes. For example the Ministry of Higher Education in Saudi Arabia states, the mission of KASP, it is meant to "prepare and qualify Saudi human resources in an effective manner so that they will be able to compete on an international level in the labor market and the different areas of scientific research, and thereby become an important source of supply of highly qualified individuals for Saudi universities as well as the government and private sectors" (Ministry of Higher Education in Saudi Arabia 2011). Bukhari and Denman believe, "the rationale for the programme [KASP] was that skills formation for the country lacked quality and focus and that workforce planning and development would be 
significantly enhanced by leaner mobility that extended beyond its borders to major international universities" (Bukhari \& Denman 2013: 151). Moreover, Prof. Abouammoh (2010) discusses the trend of reforming higher education system in Saudi Arabia, and he believes that KASP is one of the strategies that is meant to improve the economic prosperity and solve the high unemployment in Saudi Arabia (2010, p. 3). The Center for Higher Education Research and Studies (CHERS) in Saudi Arabia adds, "the scholarship is restricted to discipline[s] mostly needed by the Saudi labor market such as medical studies, engineering and business" (CHERS, 2009, p. 14). Interestingly, some scholars perceive KASP as a strategy of "promoting to a transition to a knowledge economy" (Gallarotti, 2013, 1). Hence, the argument here strongly suggests that KASP is a strategy created for economic reasons.

\subsection{Assumption 3: KASP was founded on a socio-cultural ground}

In order to make any change in the education, customs, policies, or governmental policies, decision makers need to know that the society would accept it; otherwise, the risk could be high. Therefore, in Saudi's conservative society, the change or reform would take time or ages until people tolerate and accept the change. In an interesting research conducted by Clary and Karlin, there was a little story about a discussion that happened between King Fahd (the former King of Saudi Arabia before King Abdullah) and King Abdullah. King Fahd referred to the huge improvements that Saudi Arabia has achieved, and how it has transformed from deserts into a wealthy modern country. King Fahd, however, believed that changing the country was easy, but changing the Saudis' way of thinking seemed impossible. King Abdullah, six years later, proved it wrong after considering and embracing deliberate policies to stimulate reforming the society (Clary \& Karlin, 2011, p.p 15-17; Ottaway, 2012, p. 1). In other words, King Abdullah is seen as reform-minded within the Saudi context (BBC News 2013).

Some scholars such as Ottaway declare that many Saudis presume that King Abdullah's secret objective of starting KASP is to create a critical mass of reform-minded Saudis who will eventually form a pressure group, sufficiently powerful to untie the rule of the ultra-conservative Wahhabi religious establishment over Saudi society and the pace of change (Ottaway 2012, p. 3). Coleman adds, "in fact, part of the rationale of the [KASP] program is to make Saudi Arabia a more open society" (Coleman, 2012, para. 5). She also mentioned the internal scholarship program, but she believes that its recipients will then miss the biggest benefit of the overseas scholarships, which is the exposure to more open societies (Coleman, 2012, para. 6).

Furthermore, the stated goal of the program, which Saudi Gazette in March reported, is that a lot of hope has been placed on KASP's graduates to bring a social change and create a more open society (Bashraheel, 2013, para. 4).

\section{Methodology}

The author of this study interviewed Saudi and Emirati students to investigate their viewpoints about the benefits and problems that occur, at present, or may occur to them in the future (as individuals), and/or to their countries (nation-states). Due to the scope of this particular study, emphasis will be placed on the nation-states. So, this study will present the current and potential benefits and problems for KSA and UAE from their students' perspectives.

\subsection{The Sample}

Thirty (30) students were interviewed (16 Saudis; 14 Emiratis). The 16 Saudi students who participated in the interview were comprised of 12 male students and only 4 females.

Interestingly, because the researcher is a female, she had thought that more females would agree to be interviewed by her than would males. (Disclosure: the 4 females, who were interviewed, are close friends of the researcher).

Nevertheless, the female participants expressed their perceptions generously, freely and openly. It is unknown why the other Saudi females (who are not friends of the researcher) were unwilling to participate. This is yet to be researched.

Regarding Emirati students, the 14 participants were interviewed in three main cities of Australia. With UAE's students, it was very obvious that the majority of the UAE's students are single; unfortunately the researcher could not reach any UAE female students, so the 14 interviewed students were males only.

Whilst there were commonalities and slight differences between Saudis' and Emiratis' responses, it is important to note that all 14 UAE students were undertaking bachelor-level degrees whereas the 16 Saudi students were in bachelor to $\mathrm{PhD}$ programs. 


\subsection{The Locations}

Because the sample size is small, the researcher purposely chose to interview students living in different locations in Australia. The objective of this strategy was to avoid interviewing friends from one city where a certain belief, problem, benefit or phenomenon dominates.

Accordingly, 3 interviews were conducted in New South Wales (Armidale); 18 interviews were conducted in Queensland (Brisbane) and Victoria (Melbourne) where the majority of Emirati students were concentrated. Eight interviews of Saudi and Emirati students took place in South Australia (Adelaide). Interestingly, Saudi students were located in every city whereas the majority of UAE's students were located in Brisbane and Melbourne with only a handful (5) students studying in Adelaide.

\subsection{The Findings}

\subsubsection{Benefits for KSA and UAE from sending their Students Overseas}

This section discloses other differences between Saudi and Emirati overseas students regarding their anticipations and expectations of the possible positive outcomes that KSA and UAE might gain as a result of sending their students overseas. The first two benefits from Saudis perspectives are importing new general ideas from the hosting countries and implementing them in Saudi Arabia for the purpose of the improvement; and the other benefit is modifying the higher education system.

Saudi Arabia may be perceived, in the United States, as a corrupt, absolute monarchy that supports terrorism and provides financial aid to terrorist organizations, denies its people basic democratic freedoms and human rights, keeps its women in virtual bondage, is anti-Semitic, and uses its vast oil reserves as an instrument of political power against Israel and the United States (Long, 2004, p. 24).

Hence, $25 \%$ of Saudi students presume that KASP is assisting non-Arabs, in the hosting countries, to correct the false stereotype of Islam and of Saudi Arabia. That seems to be a goal for Saudi Arabia to achieve through its students as its ambassadors. Sulaiman Abal-khail, the manager of Imam Saudi Islamic University, in a speech given to the Saudi students who are in the United States to study, asked them to focus on their academic mission first and then to participate in the American's and Canadian's activities that may increase the awareness of those people about the tolerance, flexibilities and good manners that Muslims and Saudis acquire (Imam Saud Islamic University organized a meeting with overseas students in the Saud Cultural Mission in Washington (Al-Arabiyah News, 26 March 2013).

The third facet of the anticipation focused on the positive internal changes in the Saudi culture. $15.7 \%$ of the students believed that KASP would cooperate in making the Saudi community more tolerant with other international people; as another $15.7 \%$ responses anticipated a more extroverted community. $12.5 \%$ of the students deduce that Saudis would be more respectful to human beings regardless of their variant backgrounds; and they would be more easy going and flexible with changing some of the strict customs such as preventing women from car-driving.

On UAE's side, $57.1 \%$ of Emirati students agree with their Saudi counterpart in presuming that the major benefit for their home countries is bringing the new ideas from the developed countries and implement them successfully in KSA and UAE. For essence, Eissa Al-Shamisi, a UAE student in Brisbane, believes, "Australia has many advanced policies and strategies concerning education, infrastructure, preserving environment, etc....if we (overseas students) go back to UAE and help the government to implement some of these advanced policies for the purpose of the improvement, UAE can be as developed as the other developed countries and compete against them".

Interestingly, $50 \%$ of Emiratis postulate that by sending them to different countries, UAE would have a chance to build stronger relations with those various hosting countries. Khalid Al-Mazrouei states, "when UAE sends us (its students) to study in the different developed countries, UAE will make mutual deals which will result in strengthening the relations between those countries...A good example, is the cooperation and partnership between Emirates airways and the Australia national airways 'Qantas'...I think that indicate a bright future in terms of the international cooperation for UAE", an Emirati student in Melbourne, http://www.accc.gov.au/media-release/accc-grants-interim-authorisation-to-alliance-between-qantas-and-emiratesacc essed in 28 March 2013

$42 \%$ believe that UAE could have a better reputation and stereotype in the hosting countries through its behaving students. "Most of the people think that the Gulf Arab countries are about desert, oil and tent...but now people are getting to know that we are far more advanced than they think" Mohammad Al-Dhaeri said, a UAE student in 
Brisbane. Moreover, $18.75 \%$ of UAE's students expressed that in different ways as they assume that by sending them overseas, they could give a brighter picture of Arabs and Islam.

Unlike Saudi's expectations, only $14.2 \%$ of Emiratis think that the overseas scholarship program would help to improve the educational system in UAE. With a small portion of anticipations, Emiratis tend to think that the overseas scholarship program would increase the usage of the English language country-wide; it would encourage Emiratis to be more sociable with other international people in UAE; it would enable UAE to compete with the developed countries and, finally, it would also help in reducing the reliance on the foreign workers, with $14.2 \%$ for each of these points.

In sum, the various responses from the two sides display a common theme with some disparities. First of all, Saudis and Emiratis are almost equally expecting their countries to flourish after their students return from overseas carrying new ideas that can improve different sectors. However, a large portion of Saudis anticipate a flourished educational system while Emiratis do not quite foresee this as a current benefit. Interestingly, UAE's students seem to be more optimistic about UAE's international relations and UAE's reputation. Moreover, 2 of UAE's students tackled the possible advantage of having less number of foreign workers while Saudis did not mention that. Finally, Saudis and Emiratis come into alignment with the hope for having a greater sense of flexibility and tolerance when dealing with other nations. In simple words, Saudis tend to think more about the internal changes whereas Emiratis think equally of the internal as well external benefits. The Figures $2 \& 3$ demonstrate the portion of each benefit compared with other benefits. They do not represent the number of students.

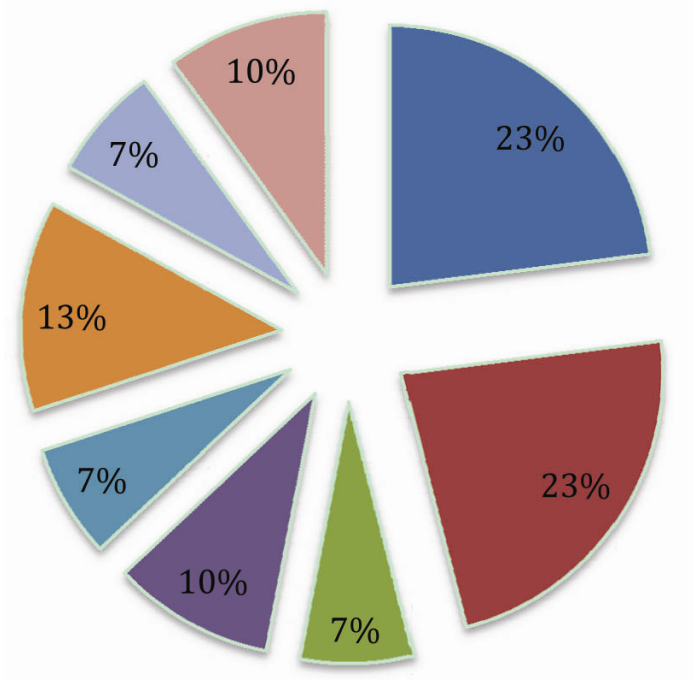
- Modifying KSA's education system
- Importing creative Ideas
m Correcting wrong customs
- KSA's people are more tolerant
= KSA's people are more respecting for others
- Correcting theKSA's stereotype
- KSA's people are willing to accept cultural changes
- KSA's people become more open-min

Figure 2. Benefits for KSA from sending its students overseas

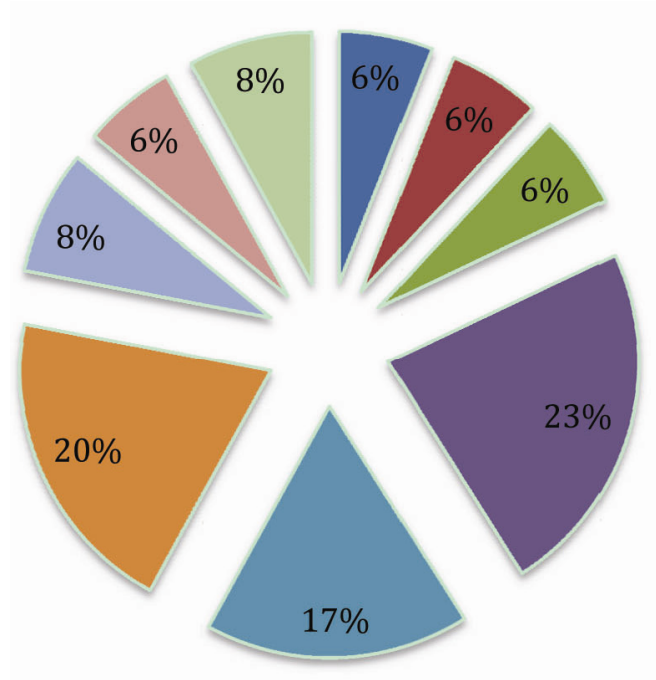

m Increasing the usage of the English

Language in UAE

- UAE's people have better skills of communication with others

m Applying different ways of teaching

n Importing creating ideas

m Modifying UAE's reputation

In Strengthening the relations between UAE and other countries

in Less foreign workers

n UAE's people are well educated

Providing brighter picture about Arabs and Muslims

Figure 3. Benefits for UAE from sending its students overseas 


\subsubsection{Problems for KSA and UAE from sending their Students Overseas}

Bearing the conservative Saudi society in mind, it is not surprising to find that $57.1 \%$ of them revealed their concern about having KSA's identity changed (this is the highest percentage that Saudi students presented in the whole interview process). "The young students are susceptible to the change... and that change can be negative if it touches their beliefs, values and manners", Mohammad Al-Khaibari said. "Foad Bogest adds, "KSA's identity can be negatively influenced by the West... some people may convert into other religions and some may get used to drinking alcohol... anyway, I fear that people would start being distant from Islam's rules". "I am afraid that Saudi Arabia would be unable to stick to Islamic nature... we started to see some young Saudi guys wearing necklaces and stuff like that", Mohammad Al-Ghamdi said. "I expect many Saudi students would return back to Saudi Arabia claiming for the kind of "freedom" that Saudi Arabia and Islam would not expect such as drinking alcohol, allowing boys and girls to have affairs outside the frame of marriage, and so on..." Anas Al-Malki said. In addition, $31.25 \%$ disclose their anxiety about importing concepts that are not in alignment with Islamic rules such as "the Valentine's Day"; and $25 \%$ talk about the chances of reduced commitment to Islam. In total, 18 responses from 16 Saudi students reveal the same concern about the detaching from KSA's identity, the resistance to the contradictory beliefs and norms, and to remain committed to Islamic rules.

Moreover, $37 \%$ of Saudi interviewees were concerned that young Saudi students may easily drift from their culture and identity. It was also believed that young students' chances in misbehaving in the hosting countries are higher which will affect KSA's reputation worldwide. Dania states, "unfortunately some young Saudi men embarrass us...I mean, for example, we (Saudi females) tell international students that, in Islam, drinking alcohol and the relationships between males and females outside the frame of marriage is forbidden...and they answer, 'but many Saudi men do these things'...I think, KSA's and Islam's reputation would be more likely misperceived by such immature behavior".

Furthermore, the rest of the anticipations are involving some economic consequences. For example, $25 \%$ of the students think that spending a huge budget on an overseas scholarship program would affect the general budget of the kingdom and KSA especially when sponsoring unqualified students. "Unfortunately a number of bachelor students apply for the scholarships only to have fun overseas and they see it as a paid vacation...they do not respect nor appreciate this exceptional opportunity we are given by our government...in this case, KSA's investment is not resulting in revenues" Rashood Al-Khaldi said. Moreover, one of KASP's problems is the fact that KSA does not have enough job opportunities for the returned students. Finally, Foad Boges adds, "the negative comparison between KSA and the hosting countries may end up with less satisfied and less patriotic Saudis...For example, some Saudi students only compare what hosting countries' governments offer to their citizens and KSA does not, therefore, they become critical of their government's policy".

On UAE's side, two students believe that there are no negative impacts for UAE that could result from sending its students overseas. Like Saudis, 57.1\% of UAE's students tend to believe that the number-one threat for UAE is protecting its identity. For example, there is a risk of finding some returned students bringing un-applicable attitudes that do not match with Islam nor with UAE's culture. Ahmed Zahir, a UAE student in Melbourne, believes, " there is an unwanted concept of freedom that is not comparable with our Islamic rules ... and I am fearful that some UAE students will get fascinated by the West's culture and therefore adopt what is acceptable and what is not accepted by UAE's culture... if that happens, then UAE will lose its unique Arab Islamic identity".

Wasting of money, to Emiratis, appear as a second problem for UAE especially when sponsoring the unqualified students, with $42.8 \%$. One of the UAE's students in Adelaide says, "I think UAE is wasting its money because the Ministry of Higher Education and Scientific Research forces many students to go to certain countries and study a specific set of disciplines which may not match their interest... that sometimes result in a less enthusiasm to continue their degrees and some of them decide to go back to UAE".

There are $28.5 \%$ of Emiratis who confidently unveil their concerns about having their country's reputation unfavorably impacted, in the hosting countries. Another $21.4 \%$ refer to the chances of impacting UAE's international relations; In both cases, the reasons of impacting UAE's reputation are caused by the misbehaviors of some UAE's teenage students. "The misbehavior of some Emirati students may reflect a bad image about UAE in the hosting countries... which affects UAE's reputation in turn" Marwan Al-Marii said.

In sum, there is a noticeable intersection between KSA's and UAE's students in this part. Both of whom, are eager to keep their religious and national identity protected and intact. More specifically, in total, there are $73.3 \%$ of Saudis and Emiratis worried about the influence over their identity. However, Saudis, to some degree, seem to be more concerned about the other social, economic and religious threats. Hypothetically, this further concern, from the Saudi 
side, can be rooted in the nature of their protective culture and community. On the other hand, UAE's students appear to be more careful about UAE's international relations than Saudis are. Both fear that their countries' reputations could be undesirably impacted according to some Saudi's or Emirati's misbehaviors. Finally, there are similar statistics between KSA and UAE regarding the concern about spending money on unqualified students. Figures 4 \& 5 display the problems for KSA and UAE from sending their students overseas, from their students' perspectives.

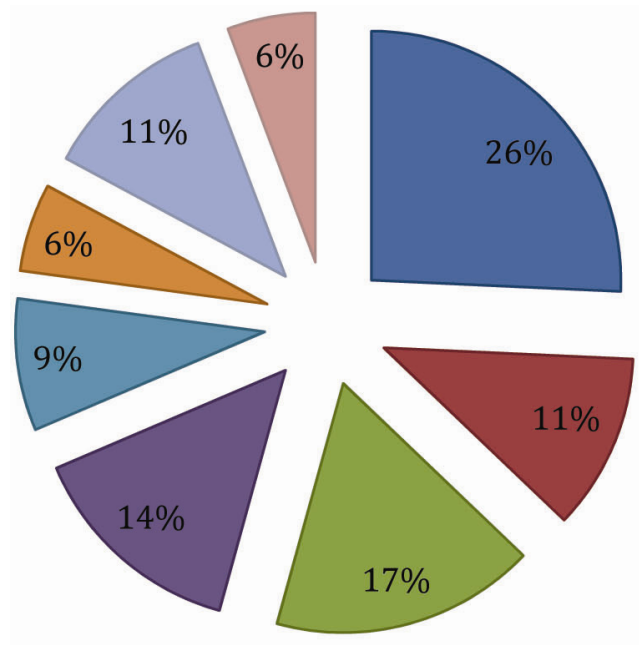

Figure 4. Problems for KSA from sending its students overseas

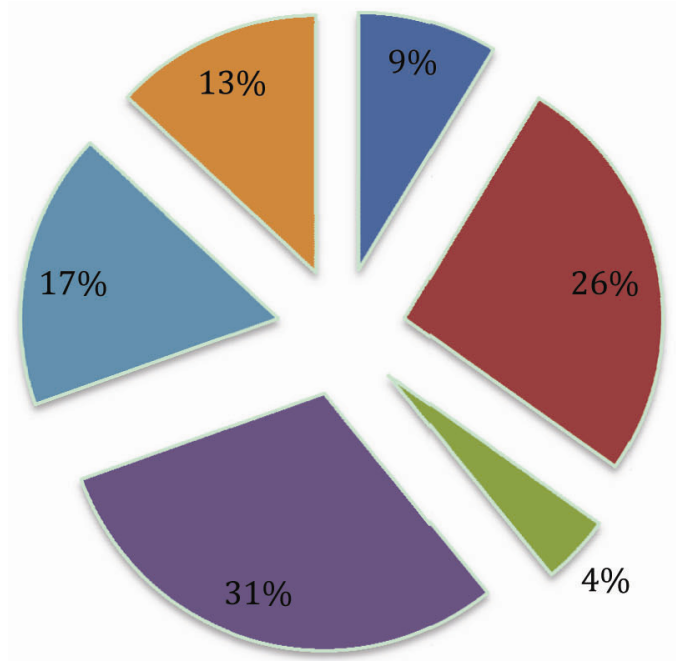

Figure 5. Problems for UAE from sending its students overseas $\square$ KSA's identity

$\square$ Waste of money

$\square$ KSA's reputation

$\square$ Import contradictory beliefs

$\square$ no available jobs

$\square$ marrying foreigner

$\square$ reduced commitment to Islam

Less sense of patriotism

चno problems so far

n waste of money

In Import contradictory beliefs

" UAE's identity

m UAE's reputation

๓⿴囗U一AE's international relations

\subsubsection{Long-term impacts on KSA and UAE from sending their students overseas}

This section forecasts the positive and/or negative influences of scholarship programs in KSA and UAE. On one hand, $50 \%$ of Saudis expect general improvement in KSA, including health, education, infrastructure, and telecommunication sectors. $31.25 \%$ predict a huge revolution particularly in education sector. "The government of Saudi Arabia is sending the students in various fields, so... I think each student possesses unique ideas, projects and goals to utilize and achieve in Saudi Arabia...that would more likely result in a marvelous revolution in different fields in KSA... I see it as one of the developed countries in 10 years time" Nojood Al-Dossary said.

Most expectedly, $43.75 \%$ of KSA's students assume that Saudi's society would be more open-minded in the next ten years. Many students shared stories and made comparison between the society before KASP begun and after. For example, Abdul-Aziz thinks, "in the near past, we were very critical to those whom worship cows (Hinduism), and we were so "anti"-the people who does not believe in God, but now, we see things differently...we have our religion and they have theirs and it is the end of the story...no big deal and it is none of our business to judge people's orientations...Moreover, not many women were working...but now the number is increasing and the government and society encourage them to enter the work field". 
Another 31.25\% of Saudi students anticipate less foreign workers in Saudi Arabia in the future. In addition, the rest of the anticipation represents only $12.5 \%$; and it includes the increased awareness and respect of Saudi Arabia outside its borders. In the opposite side, $12.5 \%$ expect "unwanted influence of non-Islamic cultures on the Saudi's culture". Fawazi Bukhari stated, "the extra open-mindedness can be negative from the religion's perspective".

From UAE's students' perspectives, $50 \%$ of them anticipate westerners to be more understanding and tolerant with Arabs and Islam. Moreover, $28.5 \%$ of Emirati students foresee UAE as a developed country as a result of implementing the ideas/policies students import from overseas. With the same portion of expectations, UAE's students disclose their willingness to amend, strengthen and reconnect their relationships with the foreign workers inside their country. Furthermore, $21 \%$ anticipate the following outcomes: less foreign workers in UAE, more open minded Emiratis, more sensitive to other cultures, and ultimately UAE would be more respected by those cultures. In other words, they are hopeful for a mutual and robust respect between UAE and other cultures/countries. Finally, 14\% of the interviewed students believe the scholarship program would lift UAE to be an international destination for business as well as for education in ten years time.

Overall, Saudis tend to be optimistic about an overall improvement in Saudi Arabia as a long-term benefit descending from KASP. More interestingly, they are willing and looking forward to having a more open-minded society, those two expectations seem to be the most important ones to the interviewed Saudi students. On the other hand, UAE's students' answers reveal that at least half of them are expecting more acceptance and understanding from the West to Arabs and Muslims. Generally, Saudis and Emiratis agree on different potential benefits for their countries in ten years time. For example, both believe that their countries would be classified as developed countries, they also expect a well-educated nation, less foreign workers, and both are hopeful that the west will correct the misperception regarding Islam and Arabs and replace this with a brighter image. Figures $6 \& 7$ demonstrate the potential impacts of the overseas scholarship program, on KSA and UAE.

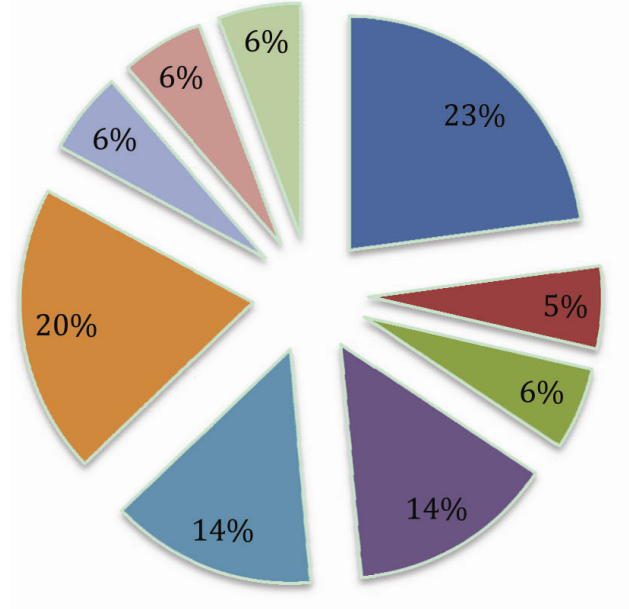

$$
\begin{aligned}
& \text { Eeneral improvement } \\
& \text { - Brighter perception of Islam } \\
& \text { wider usage of the English language } \\
& \text { across KSA } \\
& \text { n Educational revolution } \\
& \text { n less foreign workers } \\
& \text { In open-minded society } \\
& \text { rin well educated nation } \\
& \text { nSA would be a developed country } \\
& \text { KSA would have new and different }
\end{aligned}
$$

Figure 6. Possible impact of the overseas scholarship program on KSA's future

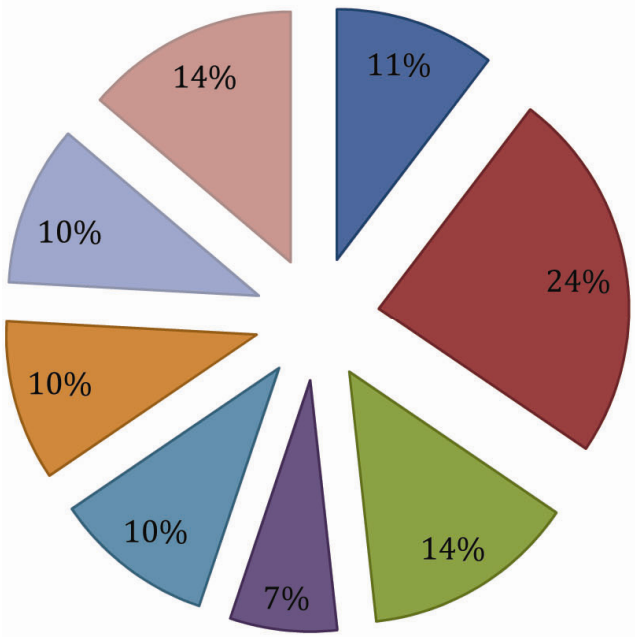

口 Less foreign workers

$\square$ Westerners would be respectful to Arabs and Muslims

$\square$ Well educated nation

口UAE as destination for education

$\square$ more open-minded society

$\square$ UAE would be more aware of other cultures

$\square$ UAE's reputation would be more respected

$\square$ stronger relations between UAE and the other countries

Figure 7. Possible impact of the overseas scholarship program on UAE's future 


\section{Conclusion}

Higher education seems to be the magic wand that Saudi Arabia is using in order to cope with its internal and external challenges. Because KASP was established in 2006/2007, the expected or wanted goals cannot be accurately foreseen at this stage. In addition, the unstable situation in the Middle East (i.e. Arab Spring) may confuse people about the real drives behind the new/amended policies in Saudi Arabia. Is KASP responsible for all of these changes? Are these changing being implemented by KSA to maintain the internal peace? Or is it for both reasons? Nevertheless, these are some possible indications of the impacts of KASP on different levels.

On a political level, for example, Boston's horrific bombings can be a measurement as to how things were during 9/11 compared with now. For instance, during 9/11, there were only around 5,579 Saudi students enrolled in the U.S higher education institutions (Jeffrey, 2013, para. 2); and after 9/11, they were neither encouraged by their families in Saudi Arabia nor by the U.S. government and citizens, to stay in the U.S. In 2011/2012, however, the number has increased to $500 \%$ with 34,139 students (Jeffrey, 2013, para. 1). When one of the first suspects was a 20-year old Saudi student (Celona, 2013, para. 1), President Obama asked Americans not to prejudge. It seems as if USA and Saudi Arabia are keen on keeping the Saudi-US relations intact this time. On a parallel level, Saudi students and U.S. citizens do not appear as alert and cautious with one another this time.

On a social level, in January 2013, King Abdullah Bin Abdul Aziz issued a historic decree allowing women to be members of the kingdom's Shura Council (Parliament) for the first time (Al Arabiya News, 2013, para. 1). Moreover, the Shura Council, in Saudi Arabia, is about to announce amended policies regarding women driving cars, and changing the weekend days from Thursday-Friday to Friday-Saturday. Although the latest is being considered for economic reasons, it is a change in the Saudi society.

On an economic level, it can be the hardest to measure at this time, as Saudi Arabia has around 130,000 of its students overseas. Therefore, the question will remain open until they return home. Saudi Arabia has spent millions of dollars to get its students trained and educated in the best universities around the world; to what extent can Saudi Arabia shrink its dependence on expatriates? Would the returned students accept the "dirty jobs", or would their expectations get the best out of them? Yet, the Ministry of Labor in Saudi Arabia has established a new scheme called "Nitaqat" which aims "to boost employment among local citizens and reduce the number of expatriates" (Sadi, 2013, p. 44). With this scheme, the Ministry of Labor evaluates all the private and public companies according to their efforts of employing Saudis. For instance, institutions are classified as Excellent, Green, Yellow, and Red. The excellent and green institutions are those who employ more of Saudi nationals, and they get support and reward from the ministry. On the other hand, the yellow and red are considered to be in the "dangerous zone" as the ministry of labor can provide fewer support and facilities (Ministry of Labor).

To conclude, Saudi Arabia seems to be in its golden age under the monarch of the 'reformer' King Abdullah bin Abdul Aziz (Meo, 2013, para. 1); a lot has positively changed since he was accounted as a King i.e. infrastructure, education, facilities to unemployed, women rights; besides other things that history will not discard.

\section{References}

[Online] Available: http://en.wikipedia.org/wiki/Saudi_Arabia

[Online] Available: http://en.wikipedia.org/wiki/United_Arab_Emirates

Abouammoh, A. M. Higher Education in the GCC States: Reforms and Regulations. [Online] Available: http://faculty.ksu.edu.sa/abouammoh/Workshops/ABOUAMMOH\%20AL\%20JISR\%203RD\%20WORKSHOP \%20JUNE\%206-9\%202010\%20DUBAI\%20UAE_SH\%20edited\%20version.pdf

Al-Arabiya News. (2013, January 11). Breakthrough in Saudi Arabia: women allowed in Parliament. [Online] Available: http://www.alarabiya.net/articles/2013/01/11/259881.html

Al-Arabiya News. (26 March 2013). Al-Imam University organized the first meeting with overseas scholarship recipients. [Online]

Available: http://www.alarabiya.net/ar/saudi-today/2013/03/26/\%D8\%AC\%D8\%A7\%D9\%85\%D8\%B9\%D8\%A9-\%D8\% A7\%D9\%84\%D8\%A5\%D9\%85\%D8\%A7\%D9\%85-\%D8\%AA\%D8\%A8\%D8\%A7\%D8\%AF\%D8\%B1-\%D8 \%A8\%D8\%AA\%D9\%86\%D8\%B8\%D9\%8A\%D9\%85-\%D8\%A3\%D9\%88\%D9\%84-\%D9\%84\%D9\%82\%D8 \%A7\%D8\%A1-\%D8\%A8\%D8\%A7\%D9\%84\%D9\%85\%D9\%88\%D9\%81\%D8\%AF\%D9\%8A\%D9\%86-\%D9 \%81\%D9\%8A-\%D8\%A8\%D9\%84\%D8\%A7\%D8\%AF-\%D8\%A7\%D9\%84\%D8\%A7\%D8\%A8\%D8\%AA\%D 8\%B9\%D8\%A7\%D8\%AB.html 
Bahgat, G. (1999). "Education in the Gulf Monarchies: Retrospect and Prospect." International Review of Education.Vol. 45, No. 2 (1999), pp. 127-136. http://dx.doi.org/10.1023/A:1003610723356

Ball, S. J., (1990). Politics and Policy Making in Education: Explorations in Policy Sociology, Routledge, Oxon, United Kingdom.

Barber, M., Mourshad, M., Whelan, F. (2007, Special Edition). Improving education in the Gulf. The McKinsey Quarterly, pp. $38-47$.

Bashraheel, L. (2013, March 11). Scholarship students: Big dreams, slow change. Saudi Gazette. [Online] Available: http://www.saudigazette.com.sa/index.cfm?method=home.regcon\&contentid=20130311156300 accessed on 12 April

BBC News (2013, Feb 20). Profile: Saudi Arabia: Head of state, prime minister: King Abdullah Bin-Abd-al-Aziz Al Saud. [Online] Available: http://www.bbc.co.uk/news/world-middle-east-14703478

Bereday, G. Z. (1964). Reflections on Comparative Methodology in Education, 1964 - 1966.Comparative Education, 3(1), 169-287. http://dx.doi.org/10.1080/0305006670030304a

British Council. (2009). Higher Education in the UAE. [Online] Available: www.britishcouncil.org/country_partnership_meeting_june_09_tne.ppt

Bukhari, F. \& Denman, B. (2013). Student Scholarships in Saudi Arabia: Implications and Opportunities for Overseas Engagement. In L. Smith \$ A. Abouammoh (Eds.), Higher Education in Saudi Arabia (151-158). Netherlands: Springer

Celona, L. (2013, April 16). FBI grills Saudi man in Boston bombings. New York Post. Retrieved from: http://www.nypost.com/p/news/national/fbi_grills_saudi_man_XaT5rE40LDdAH44vMFOEXM

Center for Higher Education Research and Studies (CHERS). (2009). Development of Higher Education in the Kingdom of Saudi Arabia: Trends and Strategies. Riyadh, Saudi Arabia: Abdullah A. Mazi \& Abdulrahman M. Abouammoh. For presentation at the Global Higher Education Forum GHEF09 13-16 December, 2009, PenangMalaysia.

Clary, C., \& Karlin, M. E. (2011). Saudi Arabia's Reform Gamble. Survival, 53(5), 15-20. http://dx.doi.org/10.1080/00396338.2011.621619

Coleman, I. (2012, June). Saudi Arabia's Study Program. [Online] Available: http://blogs.cfr.org/coleman/2012/06/26/saudi-arabias-study-abroad-program/\#

Davis, N. \& C. Hayashi (2007), The Gulf Co-operation Council (GCC), Countries and The World: Scenarios to 2025: Implications for Competitiveness. In: M.D. Hanouz, S.El Diwany \& T.Yousef, eds.,2007 Arab World Competitiveness Report, pp. 129-141. Geneva: World Economic Forum.

Denman, B. (2004). "What is a University in the 21st Century?" was presented at the IMHE/OECD conference

Denman, B. and Hilal, K. (2011). "From barriers to bridges: An investigation of Saudi student mobility (2006-2009)." International Review of 299-318. http://dx.doi.org/10.1007/s11159-011-9221-0

Economist Intelligence Unit. (March 2009a). The GCC in 2020: Outlook for the Gulf and the Global Economy. Qatar, The Qatar Financial Centre Authority: 24. [Online] Available: http://graphics.eiu.com/marketing/pdf/Gulf2020.pdf

Economist Intelligence Unit. (September 2009b). The GCC in 2020: The Gulf and its People. Qatar, The Qatar Financial Centre Authority: 22. [Online] Available: http:/graphics.eiu.com/upload/eb/Gulf2020part2.pdf

Gallarotti, G. M. (2013). Smart Development: Saudi Arabia's Quest for a Knowledge Economy. International Studies. Division II Faculty Publications. Paper 128.

Gause, F. G. (1994). Oil Monarchies: Domestic and Security Challenges in the Arab Gulf States. New York: Council on Foreign Relations Press.

Gause, G. (1997). "The Gulf Conundrum: Economic change, population growth, and political stability in the GCC states." The Washington Quarterly20(1): 142-165. http://dx.doi.org/10.1080/01636609709550234

Gause, G. (Spring 2002). "Be Careful What You Wish for: The Future of U.S.-Saudi Relations." World Policy Journal19(1): 37-50. 
Gonzalez, Gabriella, Lynn A. Karoly, Louay Constant, Hanine Salem, and Charles A. Goldman (2008). Facing Human Capital Challenges of the $21^{\text {st }}$ Century. Rand-Qatar Policy Institute, Santa Monica, California.

GulfTalent.com (2012). Employment and Salary Trends in the Gulf Overview of the Job market and key developments, covering: Saudi Arabia, Kuwait, Qatar, Bahrain, and Oman and United Arab Emirates. Seventh annual review of labor markets. [Online] Available: http://www.gulftalent.com/home/Employment-and-Salary-Trends-in-the-Gulf-2012-Report-33.html

Harold J. Noah \& Max A. Eckstein (1998). Doing Comparative Education: Three Decades of Collaboration (Hong Kong; Comparative Education Research Centre, Hong Kong.

Hilal, K. T., \& Denman, B. D. (2013). Education as a Tool for Peace?The King Abdullah Scholarship Program and Perceptions of Saudi Arabia and UAE post 9/11. Higher Education Studies, 3(2), p24. http://dx.doi.org/10.5539/hes.v3n2p24

Jeffery, T. (2013, April 22). Saudi Students in U.S. Up more than 500\% since Sept. 11, 2001. Family Security Matters.

[Online]

Available: http://www.familysecuritymatters.org/publications/detail/saudi-students-in-us-up-more-than-500-since-sept-112001

Kapiszewski, A. (2006). Arab Versus Asian Migrant Workers in the GCC Countries, United Nations Expert Group Meeting on International Migration and Development in the Arab Region, Beirut 2006

Knickmeyer, E. (2012, Nov. 8). Saudi Students Flood In as U.S. Reopens Door.TheWall Street Journal.Retrieved from http://online.wsj.com/article/SB10001424052702304830704577492450467667154.html accessed on 18 March 2013

Long, D. E. (2004). US-Saudi Relations: Evolution, Current Conditions, and Future Prospects. Mediterranean Quarterly, 15(3), 24-37. http://dx.doi.org/10.1215/10474552-15-3-24

Lyons, Jonathon. (2009). The House of Wisdom.How the Arabs Transformed Western Civilization. Bloomsbury Press, New York.

Marrou, H.I., (1956). A History of Education in Antiquity. Translated by George Lamb. Sheed and Ward Publishers, London.

Meo, S. (2013, January 4). Saudi Arabia's 'golden age of learning' under King Abdullah. Arab News. Retrieved from: http://www.arabnews.com/saudi-arabia's-'golden-age-learning'-under-king-abdullah

Ministry of Higher Education in Saudi Arabia, the mission of KASP. [Online] Available: http://www.mohe.gov.sa/en/studyaboard/King-Abdulla-hstages/Pages/mission-a.aspx

Ministry of Labor in Saudi Arabia (2013). From: http://portal.mol.gov.sa/ar/Statistics/Pages/_الكتاب_الاحصائي_السنوي_لعام_1432_1433_2011_aspx-

Ottaway, D. (2012). Saudi Arabia's Race Against Time. Woodrow Wilson International Center for Scholars and former Bureau Chief, Washington Post, Cairo. Retrieved on 15 April 2013, from:http://www.wilsoncenter.org/sites/default/files/saudi_arabias_race_against_time.pdf).

Royal Embassy of Saudi Arabia in Washington, DC. (2011). King Abdullah bin Abdulaziz. [Online] Available: http://www.saudiembassy.net/about/KingAbdullah.aspx

Royal Embassy of Saudi Arabia in Washington, DC. (2011). King Abdullah bin Abdulaziz. Retrieved 1 March 2013, from: http://www.saudiembassy.net/about/KingAbdullah.aspx

Sadi, M. A. (2013). The Implementation Process of Nationalization of Workforce in Saudi Arabian Private Sector: A Review of "Nitaqat Scheme". American Journal of Business and Management, 2(1), 37-45. http://dx.doi.org/10.11634/216796061302294

Saudi Cultural Mission in U.S.A. (2010). The Goals of the King Abdullah Scholarship Programs. [Online] Available: http://www.washcouncil.org/documents/pdf/WIEC2010_PENN_STATE_Presentation.pdf

Thomas, D. (2013, January 18). How has Saudi Arabia's KASP impacted the sector? The Pie News. Retrieved 13 March 2013, from: http://thepienews.com/analysis/how-has-saudi-arabias-kasp-impacted-the-sector/

Zeigler, L. (2012, July 25). The Saudi Cultural Mission's New Headquarters. Saudi-US Relations Information Service. From: http://susris.sustg.org/2012/07/25/the-saudi-cultural-missions-new-headquarters/ 